\title{
Decision Making for Chinese Students to Receive their Higher Education in the U.S.
}

\author{
Chiangnan Chao ${ }^{1}$ \\ ${ }^{1}$ St. John's University, New York, USA \\ Correspondence: Chiangnan Chao, St. John's University, New York, USA. E-mail: chiangchao@ hotmail.com \\ Received: September 23, 2015 \\ Accepted: October 20, 2015 \\ Online Published: October 26, 2015 \\ doi:10.5430/ijhe.v5n1p28 \\ URL: http://dx.doi.org/10.5430/ijhe.v5n1p28
}

\begin{abstract}
This study examines Chinese students' decision making considerations for coming to the U.S. for their higher education. Due to the large number of Chinese students in the U.S, it is an interesting topic for educators and researchers to explore the decision making considerations Chinese students choose for studying abroad. International student enrollment plays an important role in the higher education in the U.S. and a much needed sources of financial revenue. The results indicate that Chinese students want to develop a global view and depart from the traditional Chinese system of college education. The Chinese students participated in this study want to learn more innovations and skills that prepare them for a better future. Both administrators and educators in higher education need to learn these aspects of this tiny market segment, not only for serving this small group, but also expand the cultural diversity into the whole higher education.
\end{abstract}

Keywords: Higher education, Comparative educational systems, Chinese students study in the U.S., International business education, Mobile students

\section{Introduction}

The total Chinese students in the U.S. rose from 61,765 to 274,439 from 2003/04 to 2013/14 period, a $344 \%$ increase, while the total international students rose only 54.8\%, according to Open Door report (Report of Open Door, 2015). Among the competing countries for the international students, the U.S. attracted 886,052 during the 2013-14 school year, representing over $20 \%$ of the global students, or is about $4.2 \%$ of the total number students enrolled in the U.S. These international students and their families spent about US\$27 billion in the U.S. in 2014, according to a recent US government report (Siegmund \& Rawdon, 2015). By any measure, international education makes a significant contribution to the U.S. economy. The economic impacts are not limited to the spending of these foreign students, but also their families residing in the host country (NAFSA Report, 2013). In New York State for example, the portion of this contribution was about US\$3.2 billion, which accounts for over $10 \%$ of the national total contribution made by the international students in 2014. Attracting the best students from around the world has become a large and growing global export opportunity (Lumby \& Foskett; 2015; Siegmund \& Rawdon, 2015; Zawacki-Richter \& Bedenlier, 2015). Conversely, countries that see their students study abroad normally hope that these students return home and contribute to their home economy.

The U.S. has maintained its leading position for attracting international students, while China has become the largest single source of international students studying in the United States. Chinese students not only make up a commanding 31 percent of all international students in the United States, but also account for about two-thirds of the increase in total international student enrollments in the U.S. in 2014. This strong growth is likely to continue, presenting important export opportunities for U.S. colleges and universities (Report of Open Door, 2015; Siegmund \& Rawdon, 2015). Educators and researchers seek to better understand this phenomenon and identify effective ways to serve this small population, not as an educational strategy, but also as an international trade strategy. This research, through an empirical setting focuses on the Chinese students' decision making considerations for choosing to study in the U.S. in order to provide some insights and directions for educators, university administrators, and trade administrators. Figure 1 presents the total number of Chinese students in the U.S., 2003-2014. 


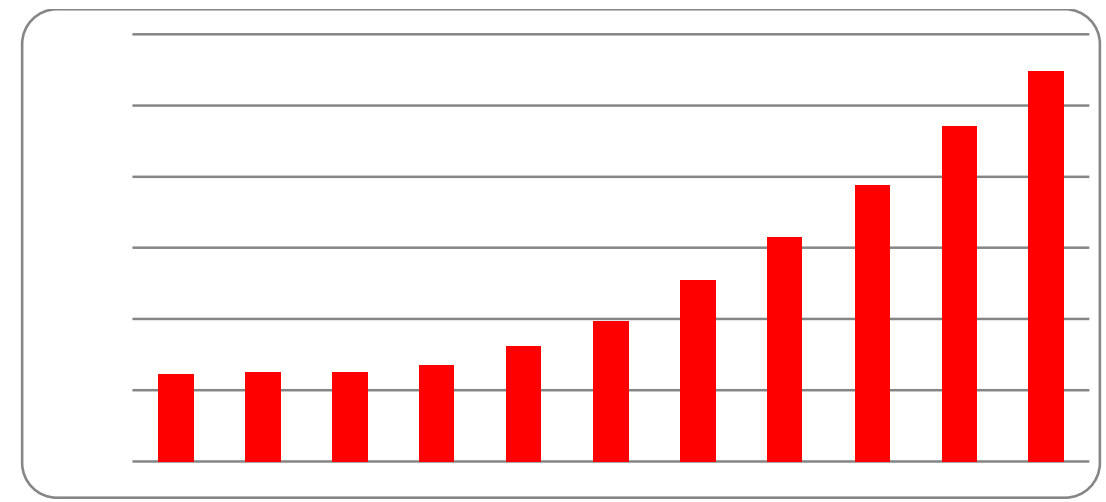

Figure 1. Total number of Chinese Students in the U.S., 2003-2014

Source: Open Doors Data, 2015.

\section{Review of Literature}

For thousands of years, education has been placed as a top priority by Chinese families. With China's economic achievements during the past decades and a shrink of family size (only one child per family), sending children to international universities has become less burdensome. In the past decade, many Chinese parents are tired of an education system that focuses mainly on academic scores at the expense of pupil's overall development. Many other drawbacks in the Chinese educational system, i.e. corruption and briberies, make many Chinese parents seriously believe to send their kids abroad for higher education better for their kids' future (Yan, 2015).

The benefits of studying abroad are felt both by individuals and entire nations. For these reasons educators and researchers are interested in the decision making considerations that Chinese students have for their endeavor for studying in the U.S. Of all international students, about $65 \%$ of source of funding comes from students' families. Meanwhile, many U.S. universities are facing an increasingly tough financial situation with a shortage of domestic students, a sharp decrease in corporate support, and declines in government subsidies. In such a situation, Chinese students with money to spend may fill that financial gap (Joseph, 2012; WES Report, 2015).

For Chinese students in the 2013/14 year, the top fields of study are business/management. Among all the major fields of study, $28 \%$ of Chinese students choose business and management that may easily enable these students find employments in China (Ortiz, Chang, \& Fang, 2015). Figure 2 presents the major fields of study for the Chinese students in the U.S. (Open Doors Data, 2013).

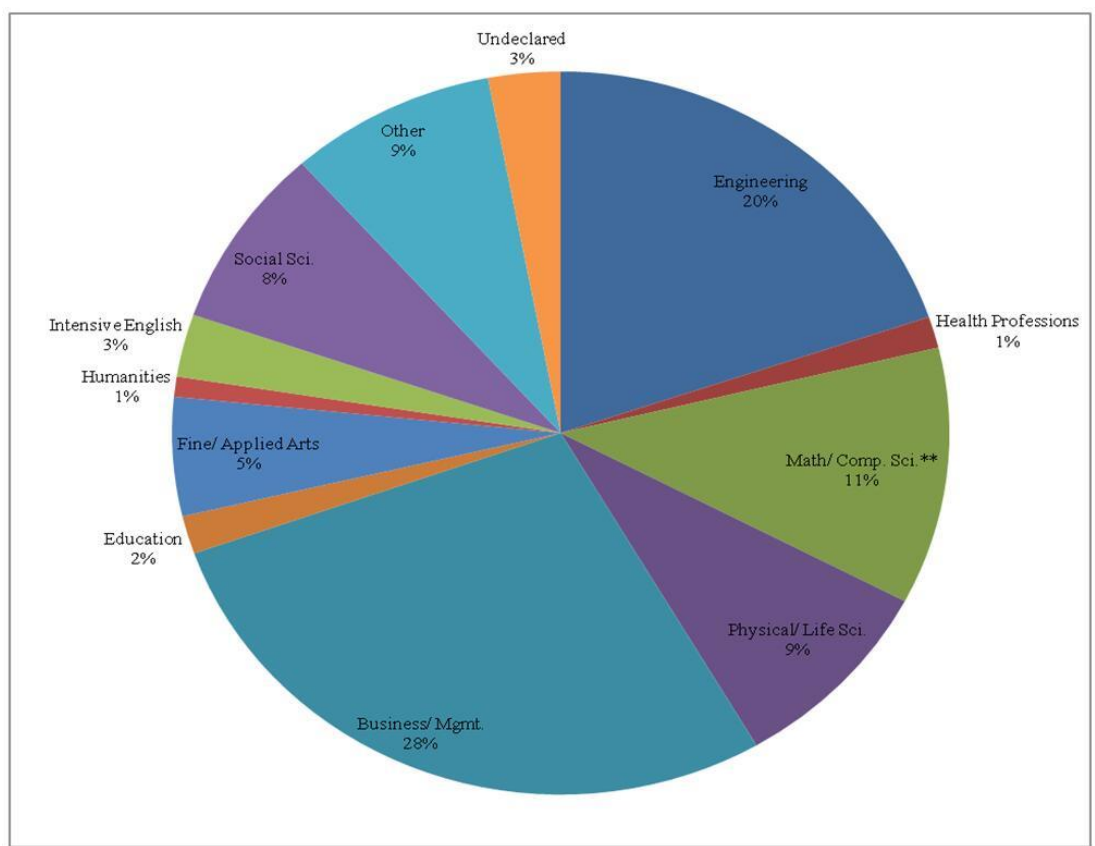

Figure 2. Major fields of studies for Chinese students in the U.S., 2014

Source: Open Doors Data, 2013 
Besides economic well being, many Chinese students decide to study abroad because they believe there is a better quality education in foreign countries. Several other factors may also influence the decision making for Chinese students to study abroad. First, more Chinese citizens are completing college and thus eligible to apply to grad school. Second, up to 1,000 universities in France, Italy, and other 14 popular overseas destinations for Chinese applicants now accept the Chinese national college entrance test scores or "Gaokao" scores as admission criteria (Ybanez, A. 2015). Third, many U.S. schools are recruiting more aggressively overseas, marketing their programs to a wider talent pool. Word of mouth then fuels the trend, as once some students attend a program; they recommend it to friends back at home. Many schools in the U.S. have set up their gateway offices in China, i.e. Columbia University and Ohio State University. Meanwhile, new specialized master's programs appeal to students, particularly those from China, eager to delve deeper into a single subject and gain a credential to compete with the growing population of educated young adults (Albrecht, Malagueno, Holland \& Sanders, 2012; Ozturgut \& Murphy, 2009; Yan, 2015).

Several recent studies have investigated the reasons and decisions for Chinese students to study overseas. The study by Bodycott (2009) reveals that some foreign institutions have to understand not just the psychology and the needs of Chinese students, but also those of their parents. Their decisions and needs may not be the only factors responsible for the choice leading Chinese students to decide to come to the U.S. The education being offered, (along with the way the institution is marketed), should effectively be aligned with China's requirements for development.

When looking into the Chinese applicants' backgrounds, many schools find some outstanding characteristics the Chinese applicants possess. First, they are China's best students who are probably aware that if they attend universities in China, they may not able to go to the best universities in the world. For example, among top 100 universities around the world, only two Chinese universities are in 39th and 67th places by the U.S. News and World Report (Best Global Universities Rankings, 2015). Unlike U.S. institutions that value candidates who present themselves as unique, their Chinese counterparts want students who excel on entrance exams that require years of rote learning and possess a strong grasp of math and science. Some critics say China's state-run education system promoted as the hallmark of Communist meritocracy - are being overrun by bribery and cronyism. Such corruption has broadened the gulf between the privileged and non-privileged classes (Levin, 2012). Third, these young individuals are ambitious and many want to go to Ivy League schools, a symbol for those parents who raise their children successfully. Fourth, they desire to learn more about critical thinking, and very importantly, they want to be exposed to things aside from just test taking (Henze \& Zhu, 2012; Ruiz, 2014; Soria1 \& Troisi, 2014; Taylor, 2012; $\mathrm{Wu}, 2014)$.

IIE published a report on motivations of the foreign students in the U.S. The report focuses on a dozen of motivations, include: 1 . Limited places available to study at (highly prestigious) universities in the home country; 2. Specialized areas which are not offered in the home country; 3 . Learn or improve knowledge of a foreign language and interest in foreign culture, history and landscape; 4. Possibility to build up networks/friendships in an intercultural context; 5. Improve career prospects/chances of getting a job in the home country, and opportunity to develop the personality/become more independent; 6 . Experience new ways of thinking and acting in the field of study (Siegmund \& Rawdon, 2015). These motivations are rather general. The other research studies what graduate courses the Chinese students choose, rather than why they choose United Kingdom as their destination (Russell, Rosenthal, \& Thomson, 2010; Zheng, 2010; Wu, 2014).

The empirical research work by Chao and Hegarty (2014) focuses on the Chinese students' reasons for attending colleges in the U.S. Their results indicate that Chinese students are seeking education with a world view and opt to break from the Chinese system of learning. Their study reveals that choosing to study in the U.S. may be an academic endeavor, but the reasons behind the choices may not be solely for academics. A different and extended research by Hegarty, et al (2014) explores decisions Chinese students make on whether or not to study in universities and colleges in the United States. This research investigates the process of decision making that leads to Chinese students studying in the United States as their preferred destination, and this research bring to light that international student enrollment is a vital component of university life and a much needed source of financial revenue. Their research finds the most important decision criteria include: 1 . Chinese students seek education with a world view; and 2. these students opt to break from the traditional Chinese educational system.

This research attempts to investigate the Chinese students' decision making process, hopefully to gain a better understanding of the decision making process, and provide a better quality education to serve this market segment. 


\section{Method}

With the focal questions in mind, this research explores Chinese students' decision making considerations for studying in the U.S. A survey was developed to investigate the issues related to the subject of this study: what are the important decision considerations for Chinese students to leave their home country and study in the U.S. The following variables are developed from literature reviews.

\subsection{Variable Selection}

The following variables serve as decisions that affect Chinese students in their decision-making for studying abroad, from the literature review.

1. I can see the world and broaden my experience;

2. I can explore my heritage;

3. I can learn a language when being with native speakers;

4. I can improve my professional and financial potential;

5. I can gain new insights and outlooks through new relationships;

6. I can take control of my future;

7. It is easy to progress academically in foreign schools;

8. I can develop some skills that are not available in my home country;

9. I can earn a more valuable degree from a foreign school;

10. There are better quality programs in schools abroad;

11. It may enable me to stay abroad;

12. I can enjoy more freedom;

13. There is better technology, i.e. computers and network, abroad;

14. There are more inspiring programs in schools abroad;

15. Critical thinking is more emphasized overseas.

\subsection{Hypothesis, Test of Hypothesis, and Sampling}

The hypotheses for this research are to find if there are any significant differences in the Chinese students' decisions for choosing to study in the U.S. rather than in China

$\mathrm{H}_{1} \quad$ There is no significant difference for Chinese students to see the world and broaden their experience, either in China or in the U.S.

$\mathrm{H}_{2} \quad$ There is no significant difference for Chinese students to explore their heritage, either in China or in the U.S.

$\mathrm{H}_{3} \quad$ There is no significant difference for Chinese students to learn English, either in China or in the U.S.

$\mathrm{H}_{4} \quad$ There is no significant difference for Chinese students to improve their professional and financial potential, either in China or in the U.S.

$\mathrm{H}_{5} \quad$ There is no significant difference for Chinese students to gain new insights and outlooks through new relationships, either in China or in the U.S.

$\mathrm{H}_{6} \quad$ There is no significant difference for Chinese students to take control of their future, either in China or in the U.S.

$\mathrm{H}_{7} \quad$ There is no significant difference for Chinese students to progress academically in schools, either in China or in the U.S.

$\mathrm{H}_{8} \quad$ There is no significant difference for Chinese students to develop skills, either in China or in the U.S.

$\mathrm{H}_{9} \quad$ There is no significant difference for Chinese students to earn a more valuable degree, either in China or in the U.S. 
$\mathrm{H}_{10}$ There is no significant difference for Chinese students to find better quality programs in schools, either in China or in the U.S.

$\mathrm{H}_{11} \quad$ There is no significant difference for Chinese students to remain, either in China or in the U.S. after graduation.

$\mathrm{H}_{12}$ There is no significant difference for Chinese students to enjoy freedom, either in China or in the U.S.

$\mathrm{H}_{13} \quad$ There is no significant difference for Chinese students to enjoy better technology, i.e. computers and network, either in China or in the U.S.

$\mathrm{H}_{14}$ There is no significant difference for Chinese students to have more inspiring programs in schools, either in China or in the U.S.

$\mathrm{H}_{15}$ There is no significant difference for Chinese students to acquire more critical thinking in schools, either in China or in the U.S.

Alternatively, there are significant differences in each of these hypotheses.

Due to the nature of this empirical study, the questionnaires were distributed to Chinese students in two large university campuses in the Northeast of the United States for a convenient sampling. The respondents were asked to evaluate the selected variables in a five point Likert scale, with $5=$ most important, $4=$ important, $3=$ neutral, $2=$ not important, and $1=$ least important.

One sample Student's $t$-test is used to test the hypotheses. A $t$-test is any statistical hypothesis test in which the test statistic follows a Student's $t$ distribution if the null hypothesis is supported. It is most commonly applied when the test statistic would follow a normal distribution if the value of a scaling term in the test statistic is known. The one sample $t$-test requires that the dependent variable follow a normal distribution. When the number of subjects in the experimental group is 30 or more, the central limit theorem shows a normal distribution can be assumed. If the number of subjects is less than 30, the researcher should plot the results and examine whether they appear to follow a normal distribution. If the distribution appears to be non-normal, and/or if the number of test cases is significantly less than 30, then a one sample median test, which does not require a normal distribution, should be used to test the hypothesis (Conover, 1980; Davis and Cosenza, 1985; Hamburg, 1977; $\operatorname{SPSS}^{\mathrm{X}}$, 2002; Wikipedia, 2012). Five percent of the $t$-Tests one tailed probability level was selected to signify the differences between preferences. When the scaling term is unknown and is replaced by an estimate based on the data, the test statistic (under certain conditions) follows a Student's $t$ distribution. The estimate value for testing hypotheses in this study is 3 , which is neutral. It shows no differences between studying either in China or in the U.S.

\section{Results and Issues}

\subsection{Results}

Over 350 respondents were surveyed, with 128 completed responded for analyses, representing 36.5 percent of the total surveyed. Table 1 presents the general background information of the respondents. 
Table 1. Backgrounds of the Respondents

\begin{tabular}{|c|c|c|}
\hline Variables & Groups & Valid \% \\
\hline \multirow[t]{3}{*}{ 1. Age } & $<18$ & 6.4 \\
\hline & $18-35$ & 92.0 \\
\hline & $>35$ & 1.6 \\
\hline \multirow[t]{2}{*}{ 2. gender } & Male & 56.0 \\
\hline & Female & 44.0 \\
\hline \multirow[t]{4}{*}{ 3. Family annual income } & $<\$ 30 \mathrm{k}$ & 33.9 \\
\hline & $\$ 30-50 \mathrm{k}$ & 26.4 \\
\hline & $\$ 50-75 k$ & 13.7 \\
\hline & $>\$ 75 \mathrm{k}$ & 25.8 \\
\hline \multirow[t]{2}{*}{ 4. Education } & College & 69.6 \\
\hline & Graduate & 30.4 \\
\hline \multirow[t]{2}{*}{ 5. Marital status } & Married & 9.6 \\
\hline & Single & 90.4 \\
\hline \multirow[t]{4}{*}{ 6. Sources of financial supports } & Parent & 56.8 \\
\hline & Own saving & 5.6 \\
\hline & Obtained scholarship or GA & 22.4 \\
\hline & Combination of various sources & 15.2 \\
\hline \multirow[t]{4}{*}{ 7. Number years studied in the U.S. } & $<1$ year & 13.6 \\
\hline & 1 year & 9.6 \\
\hline & $1-2$ years & 16.6 \\
\hline & $>2$ years & 60.0 \\
\hline \multirow[t]{4}{*}{ 8. How many schools did you apply to? } & 1 school & 14.6 \\
\hline & 2 schools & 5.7 \\
\hline & 3 schools & 16.3 \\
\hline & $>3$ schools & 63.4 \\
\hline \multirow[t]{3}{*}{ 9. If you took Gaokao, you stood at } & top $25 \%$ & 44.1 \\
\hline & $26-75 \%$ & 44.1 \\
\hline & lower $76-100 \%$ & 11.8 \\
\hline
\end{tabular}

Source: original

It is noticeable that $25.8 \%$ of the Chinese students who took the survey have a family income over US\$75K a year equivalent, and most of the students were born after 1978 when the one child per family policy was initiated (Source: http://healthland.time.com/2013/01/10/little-emperors/). In other words, these respondents had alternatives for their college selections: they could either study in China, or go abroad. More than 60 percent of the respondents have already studied in the U.S. for over two years and therefore have had ample time to affirm their reasons for leaving China.

Table 2 presents the test results of One-Sample $t$-Test, with mean differences, $t$ values, degrees of freedom, and two tailed significances of these tests. 
Table 2. One-Sample t-Test Results, test value $=3$

\begin{tabular}{|c|c|c|c|c|}
\hline \multirow[b]{2}{*}{ Variables } & \multicolumn{3}{|l|}{ Mean } & \multirow{2}{*}{$\begin{array}{l}\text { Sig. } \\
\text { (2-tailed) }\end{array}$} \\
\hline & Diff & $t$ & df & \\
\hline 1. See the world and broaden my experience. & 0.641 & 4.831 & 116 & $\mathbf{0 . 0 0 0}$ \\
\hline 2. Explore my heritage & 0.289 & 2.338 & 113 & 0.021 \\
\hline 3. Learn a language when being with native speakers & 0.539 & 4.156 & 114 & 0.000 \\
\hline 4. Improve my professional and financial potential. & 0.641 & 5.167 & 116 & 0.000 \\
\hline 5. Gain new insights and outlooks through new relationships. & 0.543 & 4.341 & 115 & 0.000 \\
\hline 6. Take control of my future. & 0.655 & 5.375 & 115 & 0.000 \\
\hline 7. It is easy to progress academically in foreign schools. & -0.009 & -0.082 & 114 & 0.935 \\
\hline 8. I can develop some skills that are not available at home country. & 0.412 & 3.279 & 113 & 0.001 \\
\hline 9. I can earn a more valuable degree from a foreign school. & 0.221 & 1.828 & 112 & $\mathbf{0 . 0 7 0}$ \\
\hline 10. There are better quality programs in schools abroad. & 0.289 & 2.326 & 113 & 0.022 \\
\hline 11. It may enable you to stay abroad. & 0.104 & 0.920 & 114 & 0.360 \\
\hline 12. I can enjoy more freedom & 0.252 & 2.178 & 114 & $\mathbf{0 . 0 3 1}$ \\
\hline 13. There are better technology, i.e. computers and network abroad. & 0.190 & 1.607 & 115 & 0.111 \\
\hline 14. There are more inspiring programs in schools abroad. & 0.289 & 2.524 & 113 & 0.013 \\
\hline 15. Critical thinking is more emphasized overseas. & 0.342 & 2.881 & 113 & 0.005 \\
\hline
\end{tabular}

Source: original

\subsection{Conclusion: Managerial Implications and Recommendations}

The test results of One-Sample $t$-Test reject twelve null hypotheses:

1. See the world and broaden my experience.

2. Explore my heritage

3. Learn a language when being with native speakers

4. Improve my professional and financial potential.

5. Gain new insights and outlooks through new relationships.

6. Take control of my future.

8. I can develop some skills that are not available at home country.

9. I can earn a more valuable degree from a foreign school.

10. There are better quality programs in schools abroad.

12. I can enjoy more freedom

14. There are more inspiring programs in schools abroad.

15. Critical thinking is more emphasized overseas.

In other words, these twelve variables present that they are more important for Chinese students' decisions to come to study the U.S., so these hypotheses are rejected. Among these rejected hypotheses, the highest positive mean differences show in variables: 6 . Take control of my future, 1 . See the world and broaden my experience, and 4. Improve my professional and financial potential, which indicate that the respondents view these as more important, these decision making considerations help the respondents leave their home country for better education.

With regard to the other three variables, the test results accept the null hypotheses: 7. It is easy to progress academically in foreign schools, 11. It may enable you to stay abroad, and 13. There are better technology, i.e. computers and network abroad which show small mean differences. The insignificances of these variables suggest that these may not be the primary decision considerations for the respondents to study in the U.S., therefore these hypotheses are accepted. 
This research concludes that non-academic decision making considerations are primarily driving force for the respondents to study in the U.S. Cultural aspects and desires to gain a non-Chinese world perspective emerge as primary decision considerations for studying in the U.S. This may be a result that China has become a global economic power house, and the respondents want to be more internationalization. These decision considerations are consistent, as all affluent middle classes who have moved beyond daily sustenance and have achieved long term security.

All universities have Missions and Visions, which encapsulate their goals and aspirations. More and more universities include international and global references into their mission and vision. The author has found that some universities do not have clearly defined global mission, though their foreign students account for over $10 \%$ of the total enrollment, and in some graduate programs Chinese students count for $60 \%$. Some administrators do not encourage nor support their faculty reaching out to countries, like China, India, or South Korea. At some universities, the travel funds for faculty are only available for academic conferences where the attendance and the global exposure may be quite limited. By contrast, as an invited guest speaker at a top Chinese university, a faculty member, who attracts thousands of attendees including students, faculty and administrators of that Chinese university, may not be supported, these universities fail in global reach, and further puzzle the targeted international market segments, including both potential students and their parents.

\subsection{Limitations and Future Research}

While this study is limited by its size, and is confined to Chinese students studying at two universities in the northeast United States, it does provide direction and insight for future research to build upon. The sample size can be accepted as a good representation of the decisions of Chinese students who wish to study in the U.S., as the northeast United States has a large number of Chinese students, as opposed to a state with very limited number of Chinese students that can make sampling non-representative.

Due to the limited sample size and issues addressed in this study, the researcher believes that there are additional issues which need to be investigated. Academic research on the decision making considerations of international student populations (4.1\% of the total U.S. college students), particularly Chinese students (about $1.2 \%$ of the total U.S. college students) in the U.S. is limited. Further, as much has been written in terms of their numbers and how universities are accommodating international students, there is limited empirical research on the understanding of 'why' Chinese students choose to study in the U.S. It is imperative in servicing this market segment that universities first understand the decision making considerations for these international students, not limited to the Chinese students, as only then can universities hope to build programs to cater to the long term facilitation of this segment. Furthermore, empirical studies would continue to serve the advancement of knowledge in this area by increasing the sample size across numerous universities, and broadening the scope by examining any differences in decisions in terms of public versus private colleges, and geographic location within the U.S.

Another recommendation is to look at any major differences between undergraduate and graduate Chinese students, as well as differences between graduate Chinese who completed bachelor degrees in the U.S. and those who didn't, an investigation on the decision making considerations of these students' parents can add better understanding of this market segment. Growing number of Chinese students in the U.S. has raised some challenging questions for both educators and administrators. In the future, researchers will need to know more about the expectations these Chinese students have when they land in the U.S. Whether these expectations are met during their studies or after their studies remain important questions for future investigations. If student expectations are not met, then educators in U.S. schools need to eliminate the gap between expectations and the actual perceptions by students. A demographic of this size cannot be ignored and needs to be understood, particularly since the trend is expected to continue well into the future.

\section{References}

Albrecht, C., Malagueno, R. Holland, D., \& Sanders, M. (2012). A Cross-Country Perspective on Professional Oversight, Education Standards and Countries' Perceived Level of Corruption, Cross Cultural Management: An International Journal, 19(4), 433-454.

Alvin Ybanez, Italy, France Now Accept Gaokao Scores, Yibada.com, Jun 26, 2015A group of Chinese students reviewing for the national college entrance exams or "gaokao." Source: http://en.yibada.com/articles/41077/20150626/italy-france-now-accept-gaokao-scores.htm\#ixzz3k81uYq4i

Best Global Universities Rankings, (2015). Retrieved from http://www.usnews.com/education/best-global-universities/rankings 
Bodycott, P. (2009). Choosing a higher education study abroad destination: What mainland Chinese parents and students rate as important, Journal of Research in International Education December 1, 2009 8, 349-373. http://dx.doi.org/10.1177/1475240909345818

Chao, C. \& Hegarty, N. (2014). Driving Forces which Enthuse the Continuous Growth of Chinese Students in U.S. Colleges: A Preliminary Study on Chinese Students' Motives, Journal of Academic Administration in Higher Education, Fall, 10(2), 27-34.

Hegarty, N., Fuxman, L., Elifoglu, I. H., \& Chao, C. (2014). Chinese Students' Decisions for Studying in U.S. Colleges: An Exploratory Investigation, Review of Business, 34(1), 81-90.

Conover, W. J. (1980). Practical Nonparametric Statistics, 2nd ed. New York: John Wiley and Sons, 213-337 and 344-384.

Davis, D., \& R. M. Cosenza. (1985). Business Research for Decision Making. Boston: Kent Publishing Company.

Hamburg, M. (1977). Statistical Analysis for Decision Making, 2nd Ed. New York: Harcourt Brace Jovanovich, Inc., 219538.

Hegarty, N., Fuxman, L., Elifoglu, I. H., \& Chao, C. (2014). Chinese Students' Decisions for Studying in U.S. Colleges: An Exploratory Investigation, Review of Business, 34(1), 81-90. Retrieved from http://healthland.time.com/2013/01/10/little-emperors/

Joseph, F. (2012). Overseas colleges fight for Chinese students. CNTV, October 19.

Levin, D. (2012). A Chinese Education for a Price, the New York Times, November 21.

Lumby, J. \& N. Foskett. (2015). Internationalization and Culture in Higher Education, Journal of Studies in International Education, January 16, 2015. http://dx.doi.org/10.1177/1741143214549978

NAFSA. (2013). The Economic Benefits of International Students to the U.S. Economy Academic Year 2012-2013. The National Association of Foreign Student Advisers. Source: http://www.nafsa.org.

Open Doors Data, (2013). from http://www.iie.org/Research-and-Publications/Open-Doors/Data/International-Students/Enrollment-Trends/194 8-2014

Ortiz, A., Chang, L. \& Fang, Y. (2015). International Student Mobility Trends 2015: An Economic Perspective, Social Science Research Network, February 2, Website: http://wenr.wes.org/2015/02/international-student-mobility-trends-2015-an-economic-perspective/

Ozturgut, O. \& Murphy, C. (2009). Literature vs. practice: challenges for international students in the U.S., International Journal of Teaching and Learning in Higher Education, 22(3), 374-385.

Report of Open Door, (2015). http://www.iie.org/Research-and-Publications/Open-Doors/Data/International-Students/Enrollment-Trends/194 $8-2014$

Ruiz, N. G. (2014). The Geography of Foreign Students in U.S. Higher Education: Origins and Destinations, Brookings, August http://www.brookings.edu/research/interactives/2014/geography-of-foreign-students\#/M10420

Russell, J., Rosenthal, D. \& Thomson, G. (2010). The international student experience: three styles of adaptation, Higher Education, 60(2), 235-249. http://dx.doi.org/10.1007/s10734-009-9297-7

Siegmund, J. \& Rawdon, B. (2015). 2015 Top Markets Report, Education--A Market Assessment Tool for U.S. Exporters, Industry \& Analysis (I\&A), International Trade Administration, U.S. Department of Commerce, 2015. Source: http://trade.gov/topmarkets/

Soria1, K. M. \& J. Troisi. (2014). Internationalization at Home Alternatives to Study Abroad, Journal of Studies in International Education, July 1, 2014 18: 261-280.

SPSS $^{\mathrm{X}}$, Advanced Statistics, 7.5. Chicago, IL: SPSS Inc. 2002.

Taylor, A. (2012). Three Reasons China's Students are Desperate to Study in America. Business Insight, October.

WES Report: International trend in higher education, an Oxford Report, (2015). Retrieved from website: https://www.ox.ac.uk/sites/files/oxford/International\%20Trends\%20in\%20Higher\%20Education\%202015.pdf; 
Retrieved from Wikipedia. (2012). http://en.wikipedia.org/wiki/Student's_t-test; $\quad$ Source: http://www-users.cs.umn.edu/ ludford/Stat_Guide/1_Sample_t.htm

Wu, Q. (2014). Motivations and Decision-Making Processes of Mainland Chinese Students for Undertaking Master's Programs Abroad, Journal of Studies in International Education, November. 18(5), 426-444.

Yan, A. (2015). Why Chinese parents are sending their children abroad to study at a younger age, South China Morning Post, $25 \quad$ March, $2015 . \quad$ Source: http://www.scmp.com/news/china/article/1747075/why-mainland-parents-are-sending-their-children-abroad-stu dy-younger-age?page=all

Ybanez,

A. (2015).

Source: http://en.yibada.com/articles/41077/20150626/italy-france-now-accept-gaokao-scores.htm\#ixzz3k81uYq4i

Zawacki-Richter, O. \& Bedenlier, S. (2015). Internationalization of higher education and the impacts on academic faculty members, Journal of Studies in International Education, June 1, 10, 185-201.

Zheng, X. (2010). Re-interpreting silence: Chinese international students' verbal participation in U.S. universities, The International Journal of Learning, 17(5), 451-464. 